\title{
КРИМІНАЛІСТИЧНА ХАРАКТЕРИСТИКА ПРЕДМЕТІВ ДЕКЛАРУВАННЯ НЕДОСТОВІРНОЇ ІНФОРМАЦІЇ
}

\begin{abstract}
Анотація. У статті розглядається криміналістична характеристика підозрюваних та обвинувачених у декларуванні недостовірної інформації.

Встановлено, що суб'єктом декларування недостовірної інформації здебільшого є громадяни України, чоловічої статі, несудимі, які досягли 20 річного віку і вище, переважно мають вищу освіту, досвід роботи в певній сфері службової діяльності.

Аргументовано, що для методики розслідування декларування недостовірної інформації важливе значення мають окремі спеціальні риси особи злочинця: 1) статус службової особи; 2) мотиви та мета злочинної діяльності; 3) наявність значних фінансових можливостей, які можна використати як для забезпечення високого рівня надання правової допомоги, так і для організації протидії розслідуванню; 4) наявність корупційних зав'язків в органах державної влади, зокрема серед правоохоронних органів; 5) вчинення злочинів одноособово.

Здійснено класифікацію осіб, які підозрюються чи обвинувачуються в декларуванні недостовірної інформації залежно від різновиду суб'єкта декларування, за належність до службових осіб на момент вчинення злочину та залежно від способу вчинення злочину.

Встановлено, що дії слідчого під час розслідування декларування недостовірної інформації зорієнтовані на встановлення факту розбіжностей між відомостями, відображеними в декларації, і даними, що існують в об'єктивній дійсності. Таким чином, тільки так можна довести наявність завідомо недостовірних відомостей, поданих до декларації.

Ключові слова: декларування недостовірної інформації, криміналістична характеристика, предмет злочинного посягання, декларація особи, уповноваженої на виконання функцій держави або місцевого самоврядування, завідомо недостовірні відомості.
\end{abstract}

Постановка проблеми. У технологіях декларування недостовірної інформації помітне місце відводиться предмету злочинного посягання, який є джерелом інформації, необхідної для організації ефективного досудового розслідування зазначеної категорії кримінальних правопорушень. Важливе значення має саме криміналістична інформація про предмет злочинного посягання, оскільки вона визначає напрям розслідування. Предмет декларування недостовірної інформації тісно пов'язаний зі способами його вчинення та особою злочинця. Злочинці зазвичай вживають заходів щодо приховування предмета декларування недостовірної інформації або ж надання йому легальної форми.

Аналіз останніх досліджень і публікацій. Питання криміналістичної характеристики декларування недостовірної інформації розглянуті фрагментарно у працях О.С. Бондаренко,
I.В. Бульби, К.П. Задоя, I.I. Митрофанова, В.А. Пересади, О.Ю. Татарова, 3.М. Топорецької, Р.М. Шехавцова та ін. У цих роботах основна увага зосереджена на законодавчих положеннях, що характеризують декларацію, iї типи та інформацію, яку містить цей документ [1, с. 5; 2, с. 42; 3, с. 226-227, 234-239; 4, с. $125 ; 5$, с. $266-273 ; 7$, с. $155 ; 7$, с. $156-166]$. Водночас розроблення ефективної методики розслідування цього злочину неможливе без розкриття основних положень криміналістичної характеристики предметів декларування недостовірної інформації.

3 огляду на це метою статті є дослідження криміналістичної характеристики предметів декларування недостовірної інформації.

Виклад основного матеріалу. Предметом декларування недостовірної інформації є 1) декларація особи, уповноваженої на виконання функцій держави або місцевого самоврядування; 2) завідомо недостовірні відомості подані до такої декларації.

Декларація особи, уповноваженої на виконання функцій держави або місцевого самоврядування, - це офіційний документ, що подається: особами, уповноваженими на виконання функцій держави або місцевого самоврядування; особами, які претендують на заняття чи обрання на такі посади; особами, які звільняються із цих посад, компетентному органу, у встановлені законодавством строки, на підставі яких здійснюється моніторинг способу життя декларанта та фінансова перевірка його доходів, витрат і зобов'язань фінансового характеру $[1$, c. 5]. Цей документ має електронну форму і заповнюється на офіційному веб-сайті НАЗК.

Нині існують такі типи декларацій: 1) щорічна декларація особи, уповноваженої на виконання функцій держави або місцевого самоврядування; 2) декларація суб'єкта декларування, який припиняє діяльність, пов'язану 3 виконанням функцій держави або місцевого самоврядування; 3) декларація суб'єкта декларування, який припинив діяльність, пов'язану з виконанням функцій держави або місцевого самоврядування; 4) декларація суб'єкта декларування, який є особою, що претендує на зайняття посад, зазначених у п. 1, пп. «а» п. 2 ч. 1 ст. 3 Закону України «Про запобігання корупції», що подається до призначення або обрання особи на посаду.

Водночас предметом злочинного посягання у кримінальних провадженнях щодо злочину, передбаченого ст. 366-1 КК України, є лише перші три типи декларацій.

Під час розслідування декларування недостовірної інформації, як правило, не виникає проблем з ідентифікацією декларації певного типу, яка не була подана.

Найбільш складною є ситуація зі встановленням недостовірних відомостей у декларації, оскільки відсутні чіткі рекомендації із цього приводу 
Проблема насамперед полягає в тому, що чітко не визначено, які відомості, подані до декларації, можна визнати завідомо недостовірними.

Завідомо недостовірні відомості, подані до декларації, визначають по-різному, зокрема як інформацію, що має неправдивий, хибний характер, який суб'єкт декларування усвідомлював або міг усвідомлювати на момент подання декларації, згаданої у ст. 366-1 КК України [8, с. 886]; приховану, неправильну інформацію, яка до моменту внесення суб'єктом декларування в декларацію була відомою декларанту і усвідомлювалася повною мірою [2, с. 42]; перекручені відомості в декларації про існуючі об'єкти оподаткування або в умовчанні про їх наявність, коли таке умовчання свідчить не тільки про неповноту інформації, але і про їі хибність, що має місце, наприклад, у випадку неповідомлення всіх банківських рахунків декларанта [4, с. 125]; розбіжності доходів і витрат суб'єкта декларування (достатність офіційно отриманих доходів для придбання та/або утримання майна; неправдиві відомості щодо наявності та/або доходів від нерухомого майна, рухомого майна, корпоративних прав, нематеріальних активів, будь-яких інших доходів), вартість яких відрізняється від достовірних на суму понад 250 прожиткових мінімумів для працездатних осіб [9, с. 32].

Відповідно до Порядку проведення контролю та повної перевірки декларації особи, уповноваженої на виконання функцій держави або місцевого самоврядування, затвердженого Рішенням НАЗК від 10 лютого 2017 р. № 56, недостовірність задекларованих відомостей - невідповідність дійсності відомостей, зазначених у декларації суб'єкта декларування, що встановлюється на підставі відомостей, отриманих НАЗК у встановленому Законом порядку шляхом здійснення контролю та повної перевірки декларації [10].

Обов'язковою ознакою неправдивої інформації є їі завідома неправдивість. Саме завідомість підтверджує умисну форму вини цього злочину.

Водночас під час розслідування декларування недостовірної інформації слід звернути увагу на той факт, що в декларації вказуються дані, які декларанту надаються також членами його сім'ї, які, у свою чергу, можуть повідомити і недостовірну інформацію, оскільки вони не є суб' єктами декларування і до будь-якої з видів відповідальності за невиконання правил заповнення декларації притягуватися не будуть. Звідси випливає, що суб'єкт декларування може бути притягнутий до кримінальної відповідальності за внесення «завідомо недостовірних відомостей», не вважаючи останні такими [2, с. 41].

На практиці стає досить складним відмежувати недостовірність від звичайної описки чи арифметичної помилки в антикорупційній декларації, що, у свою чергу, може стати базисом для зловживань із боку органів фіскального контролю, антикорупційного запобігання і досудового розслідування та неминуче призведе до порушення прав громадян [9, с. 32].

Відтак у разі встановлення відсутності ознак завідомості слідчому доведеться закрити кримінальне провадження. Однак слід мати на увазі, що трапляються випадки, коли суб' єкт декларування свідомо подає неправдиві відомості, достовірно знаючи, що вони неправдиві, посилаючись на неправдиву інформацію членів сім'ї. Тому така позиція підозрюваного чи обвинуваченого потребує перевірки.

Слід також врахувати, що, як правило, завідомо недостовірні відомості стосуються:
1) інформації, яку суб'єкт декларування повинен був повідомити, одна він її не повідомив;

2) повністю або частково неправдивої інформації, що відображена в декларації.

Не можна погодитися 3 позицією О.Ю. Татарова про те, що за змістом диспозиції ст. 366-1 КК будь-які відомості, які не відповідають дійсності, мають неточності або неповноту, не можуть бути предметом цього складу злочину. Такими слід вважати виключно ті відомості, які містять завідомо недостовірну інформацію, яка є неправдивою (не відповідає дійсності і подана завідомо суб'єктом декларування). Тому висновки НАЗК у частині невідображення певних відомостей не є такими, які дають можливість визначити їх як недостовірні (неправдиві або ті, які не відповідають дійсності), що свідчить про відсутність ознак складу злочину, передбаченого ст. 366-1 КК України [6, с. 155].

Будь-яке невідображення певних відомостей, які суб'єкт декларування зобов' язаний вказати, слід визнавати недостовірними відомостями. Вивчення матеріалів практики свідчить про те, що інформація про об'єкти декларування або не подається зовсім, або ж перекручується. Обидва факти органами досудового розслідування кваліфікуються як подання завідомо недостовірної інформації.

К.П. Задоя слушно наводить такі приклади відомостей, які слід уважати недостовірними (якщо вони не відповідають дійсності): а) наведено відомості не про всі об'єкти нерухомості, які належать суб'єкту декларування та членам його сім’ї на праві приватної власності або знаходяться в них в оренді чи на іншому праві користування; б) зазначено невірні дані щодо дати набуття цінних паперів у власність чи їх номінальної вартості або кількості; в) не відображено нематеріальні активи, що належать суб'єкту декларування або членам його сім'ї тощо [3, с. 226].

Недостовірна інформація може стосуватися: 1) коштів, які зберігаються готівкою чи на банківських рахунках суб'єкта декларування; 2) придбання певного майна (землі, транспортних засобів, об'єктів нерухомості тощо); 3) витрат на особисті потреби та потреби своєї сім’ї (оплата відпочинку, закордонного навчання дітей, ремонту в квартирі тощо); 4) будівництва нерухомого майна; 5) вкладання коштів у бізнес.

Завідомо неправдива інформація може стосуватися як майна та інших об'єктів, що мають вартість, так і інших відомостей, що стосуються декларування.

За результатами вивчення матеріалів 3MI, а також опитування працівників правоохоронних органів встановлено, що недостовірними відомостями, які подаються до декларації, є:

1) відомості про членів сім'ї декларанта (як правило, не відображають інформації про осіб, з яким суб'єкт декларування спільно проживав, був пов'язаний спільним побутом і мав взаємні права та обов'язки сімейного характеру);

2) відомості про майно та доходи, власниками яких є члени сім’ї декларанта;

3) відомості про майно, яким користується суб'єкт декларування;

4) відомості про фактичне місце проживання суб'єкта декларування.

Як правило, неправдиві відомості стосуються такого майна: 1) житлових приміщень (квартира, будинок, дача); 2) інших нежилих приміщень (офіс, гараж, елінг); 3) транспортних засо- 
бів (насамперед це вартісні авто, які перебувають у користуванні суб'єкта декларування, однак належать іншим особам, зокрема його членам сім'ї); 4) земельних ділянок; 5) машино-місць; 6) корпоративних прав (частка у статутному капіталі товариства, підприємства, організації); 7) відсотків за вкладами в банках; 8) грошових активів; 9) видатків, у тому числі здійснених на користь інших осіб (видатки, як правило, не зазначають, оскільки в певних випадках вони перевищують законні доходи суб'єкта декларування за певний рік); 10) фінансових зобов'язань.

Власником такого майна зазвичай є не суб'єкт декларування, а члени його сім'ї чи інші особи. Водночас суб'єкт декларування користується лише таким майном.

Дії слідчого під час розслідування декларування недостовірної інформації зорієнтовані на встановлення факту розбіжностей між відомостями, відображеними в декларації, і даними, що існують в об'єктивній дійсності. Лише в такому випадку можна довести наявність завідомо недостовірних відомостей, поданих до декларації.

Під час розслідування подання суб'єктом декларування завідомо недостовірних відомостей у декларації необхідно встановити вартість майна або іншого предмета декларування, а також той факт, що такі відомості відрізняються від достовірних на суму понад 250 прожиткових мінімумів для працездатних осіб.

У результаті встановлення завідомо недостовірних відомостей, поданих до декларації, можна виявити ознаки інших злочинів, по відношенню до яких декларування недостовірної інформації $є$ одним із способів їх приховування.

Висновки. За результатами проведеного дослідження можна зробити окремі висновки щодо предмета декларування недостовірної інформації, які мають важливе значення для методики розслідування таких кримінальних правопорушень.

1. Предметом декларування недостовірної інформації є: 1) декларація особи, вповноваженої на виконання функцій держави або місцевого самоврядування; 2) завідомо недостовірні відомості, подані до такої декларації.

2. Предметом злочинного посягання у кримінальних провадженнях щодо злочину, передбаченого ст. 366-1 КК України, $€$ три типи декларацій: 1) щорічна декларація особи, уповноваженої на виконання функцій держави або місцевого самоврядування; 2) декларація суб'єкта декларування, який припиняє діяльність, пов'язану з виконанням функцій держави або місцевого самоврядування; 3) декларація суб'єкта декларування, який припинив діяльність, пов'язану 3 виконанням функцій держави або місцевого самоврядування.

3. Як правило, завідомо недостовірні відомості стосуються: 1) інформації, яку суб' єкт декларування повинен був повідомити, однак він іiі не повідомив; 2) повністю або частково неправдивої інформації, що відображена в декларації.

Вивчення матеріалів практики свідчить про те, що інформація про об'єкти декларування або не подається зовсім, або ж перекручується. Обидва факти органами досудового розслідування кваліфікуються як подання завідомо недостовірної інформації.

4. За результатами вивчення матеріалів ЗМI, а також опитування працівників правоохоронних органів встановлено, що недостовірними відомостями, які подаються до декларації, є: 1) відомості про членів сім’ї декларанта (як правило, не відображають інформації про осіб, з якими суб' єкт декларування спільно проживав, був пов'язаний спільним побутом і мав взаємні права та обов'язки сімейного характеру); 2) відомості про майно та доходи, власниками яких є члени сім'ї декларанта; 3) відомості про майно, яким користується суб'єкт декларування; 4) відомості про фактичне місце проживання суб'єкта декларування.

Як правило, неправдиві відомості стосуються такого майна: 1) житлових приміщень (квартира, будинок, дача); 2) інших нежилих приміщень (офіс, гараж, елінг); 3) транспортних засобів (насамперед це вартісні авто, які перебувають у користуванні суб'єкта декларування, однак належать іншим особам, зокрема його членам сім'ї); 4) земельних ділянок; 5) машино-місць; 6) корпоративних прав (частка у статутному капіталі товариства, підприємства, організаціі); 7) відсотків за вкладами в банках; 8) грошових активів; 9) видатків, у тому числі здійснених на користь інших осіб (видатки, як правило, не зазначають, оскільки в певних випадках вони перевищують законні доходи суб'єкта декларування за певний рік); 10) фінансових зобов'язань.

Jimepamypa:
1. Бондаренко О.С. Предмет злочинів у сфері службової діяльності та професійної діяльності, пов'язаної з наданням публічних послуг : автореферат... канд. юрид. наук, спец. : 12.00 .08 - кримінальне право та кримінологія; кримінально-виконавче право. Київ : Нац. акад. внутр. справ, 2016. 20 с.

2. Бульба I.В. Кримінальна відповідальність за декларування недостовірної інформації: проблемні аспекти Кримінально-правові та кримінологічні засади протидії корупції : зб. тез доп. V Міжнар. наук.практ. конф. (31 берез. 2017 р., м. Харків, Україна) / МВС України, Харків. нац. унт внутр. справ ; Кримінол. асоц. України. Харків : ХНУВС, 2017. С. 41.

3. Корупційні схеми: їх кримінально-правова кваліфікація і досудове розслідування / За ред. М.І. Хавронюка. Київ : Москаленко О.М., 2019. 464 c.

4. Митрофанов I.I. Що потрібно для подолання корупції? Кримінально-правові та кримінологічні засади протидії корупції : зб. тез доп. V Міжнар. наук.практ. конф. (31 берез. 2017 р., м. Харків, Україна) / МВС України, Харків. нац. унт внутр. справ ; Кримінол. асоц. України. Харків : ХНУВС, 2017. С. 125-126.

5. Пересада В.А. Криміналістична характеристика декларування недостовірної інформації. Вісник Луганського державного університету внутрішніх справ імені Е.О. Дідоренка. 2018. № 4 (84). С. 266-273.

6. Татаров О.Ю. Проблеми застосування ст. 366-1, 368-2 КК України в практичній діяльності. Реалізація державної антикорупційної політики в міжнародному вимірі : матеріали III Міжнар. наук.-практ. конф. (Київ, 7 груд. 2018 р.) : у 2 ч. / редкол. : В.В. Чернєй, С.Д. Гусарєв, С.С. Чернявський та ін. Київ : Нац. акад. внутр. справ, 2018. Ч. 1. С. 152-156.

7. Топорецька 3.М. Криміналістична характеристика декларування недостовірної інформації. Вісник кримінального судочинства № 2/2018. С. 156-166.

8. Науково-практичний коментар Кримінального кодексу України / Д.С. Азаров, В.К. Грищук, А.В. Савченко та ін. ; за заг. ред. О.М. Джужі, А.В. Савченка, В.В. Чернєя. 2-ге вид., перероб. і допов. Київ : Юрінком Інтер, 2018. 1104 с.

9. Бондаренко О.С. Щодо перспективи визнання недостовірної інформації предметом злочину, передбаченого статтею 366-1 Кримінального кодексу України. Кримінально-правові та кримінологічні засади протидї корупиії : зб. тез доп. V Міжнар. наук. практ. конф. (31 берез. 2017 р., м. Харків, Україна) / МВС України, Харків. нац. унт внутр. справ ; Кримінол. асоц. України. Харків : ХНУВС, 2017. С. 32. 
10. Порядок проведення контролю та повної перевірки декларації особи, уповноваженої на виконання функцій держави або місцевого самоврядування затвердженого : Рішенням НАЗК від 10 лютого 2017 p. № 56 URL : https://zakon.rada.gov.ua/laws/show/ z0201-17.

Cherenkov A. Forensic description of objects of declaration of false information

Summary. The article deals with the forensic description of objects of declaration of false information, namely, the declaration of a person authorized to perform functions of the state or local self-government, as well as knowingly false information submitted to such a declaration.

Defined types of declarations that are the subject of a criminal offense in criminal proceedings for a crime under art. 366-1 of the Criminal Code of Ukraine. It is established that as a rule, deliberately false information relates to: the information that the subject of the declaration had to notify, one did not notify it; a story or part of the false information that is reflected in the declaration.

Completed the classification of persons who are suspected or accused of declaring false information depending on the type of the subject of declaration, for belonging to officials at the time of the commission of the crime and depending on the method of committing the crime.

It was established that the investigator's actions during the investigation of the declaration of false information are aimed at establishing the fact of the discrepancy between the information presented in the declaration and the data existing in the objective reality, thus only this can prove the presence of knowingly false information submitted to the declaration.

It is argued that for the method of investigation of the declaration of false information, certain special features of the offender's personality are important: 1) the status of an official; 2 ) the motives and purpose of criminal activity; 3 ) the availability of significant financial resources that can be used both to ensure a high level of legal assistance and to the organization of counteraction to the investigation; 4) the presence of corruption lashes in state authorities, in particular among law enforcement agencies; 5) committing crimes one by one.

Key words: declaration of false information, forensic characteristic, object of criminal offense, declaration of the person authorized to perform functions of the state or local self-government, obviously false information. 